\title{
Modal Sosial Dalam Pengembangan Ekowisata di Desa Marente Kecamatan Alas Kabupaten Sumbawa
}

\author{
Diana Alfianti ${ }^{1}$, Solikatun, Ratih Rahmawati \\ Universitas Mataram
}

\begin{abstract}
Research with title of "Social Capital in Ecotourism Development in Marente Village of Alas Sub-district of Sumbawa District". This research is a qualitative research to discover and identify the forms of the social capital of society and the problems that occurred during the development process and efforts to overcome the problems in the development of ecotourism in Marente village. The research used the social capital theory by Putnam and Woolcocks. The research uses qualitative descriptive methods, data collection techniques using open and profound interview techniques, field observations and documentation results. Data analysis are data reduction, data presentation and conclusions/verifications. The results showed the form of social capital in Marente village community in the development of ecotourism consisting of values and norms, beliefs and networks. Values in the form of the attitude of friendliness, the value of togetherness, religious values and the value of environmental responsibility and norms to regulate the development of ecotourism. Community trust on ecotourism managers and related agencies. Network or cooperation relationship of the community in Marente village with village, district and provincial governments. Generally the obstacles faced in the ecotourism development are related to funds, facilities and infrastructure, technology are less good, lack of competent in human resources, lack of public awareness on tourism and environmental hygiene. Therefore, the effort is to propose funding proposals to related parties, to participate in training on ecotourism development and carried out socialization related to the importance of tourism and environmental hygiene.
\end{abstract}

Keywords : Social Capital, Ecotourism Development, Problems and Efforts

\begin{abstract}
Abstrak
Penelitian berjudul "Modal Sosial dalam Pengembangan Ekowisata di Desa Marente Kecamatan Alas Kabupaten Sumbawa" merupakan penelitian kualitatif yang bertujuan untuk menemukan dan mengidentifikasi bentuk-bentuk modal sosial masyarakat dan kendala yang terjadi selama proses pengembangan serta upaya yang dilakukan untuk mengatasi kendala dalam pengembangan ekowisata di Desa Marent. Penelitian ini menggunakan teori dan konsep modal sosial dari Putnam dan Woolcock. Penelitian ini menggunakan metode kualitatif deskriptif, teknik pengumpulan data menggunakan teknik wawancara terbuka dan mendalam, observasi lapangan dan hasil dokumentasi. Analisis data yang digunakan adalah reduksi data, penyajian data dan penarikan kesimpulan/verifikasi. Hasil penelitian menunjukkan bentuk modal sosial masyarakat Desa Marente dalam pengembangan ekowisata yang terdiri dari nilai dan norma, kepercayaan serta jaringan. Nilai berupa sikap keramah-tamahan, nilai kebersamaan, nilai agama dan nilai kepedulian terhadap lingkungan serta norma untuk mengatur pengembangan ekowisata. Kepercayaan masyarakat terhadap pihak pengelola ekowisata dan dinas-dinas terkait. Jaringan atau hubungan kerja sama masyarakat Desa
\end{abstract}

\footnotetext{
11dianaalfianti4887@gmail.com
} 
Marente dengan pemerintah desa, daerah maupun provinsi. Umumnya kendala yang dihadapi dalam pengembangan ekowisata yaitu terkait dengan dana, sarana dan prasarana, teknologi yang kurang baik, kurangnya SDM yang kompeten, kurangnya kesadaran masyarakat terhadap pariwisata dan kebersihan lingkungan. Sehingga upaya yang dilakukan yaitu dengan mengajukan proposal pendanaan kepada pihak terkait, mengikuti pelatihan mengenai pengembangan ekowisata serta melaksanakan sosialisasi terkait pentingnya pariwisata dan kebersihan lingkungan.

Kata Kunci : Modal Sosial, Pengembangan Ekowisata, Kendala dan Upaya

\section{Pendahuluan}

Indonesia merupakan salah satu negara yang memiliki banyak potensi alam baik di daratan maupun di lautan. Keanekaragaman flora, fauna dan karya cipta manusia yang memiliki nilai jual untuk dikembangkan menjadi sebuah usaha dibidang pariwisata. Indonesia sebagai negara maritim memiliki potensi perairan yang sangat melimpah. Kondisi tanah yang subur menjadikan Indonesia sebagai pusat perhatian kelompok manusia untuk menetap dan mengembangkan usahanya masing-masing, sedangkan potensi perairan yang berupa lautan dan pantai merupakan salah satu obyek wisata yang banyak digemari oleh wisatawan nusantara maupun wisatawan mancanegara. Hal ini dikarenakan Indonesia merupakan negara tropis yang dapat dimanfaatkan sebagai kegiatan di bidang pariwisata (Asmin, Fardinal. 2017).

Menurut Dinas Kebudayaan dan Pariwisata NTB, Provinsi Nusa Tenggara Barat merupakan salah satu Provinsi di Indonesia yang menyimpan banyak potensi pariwisata, seperti keindahan alamnya yang mempesona, beragam tradisi dan budaya yang menarik serta bermacam-macam jenis makanan tradisional dengan ciri khas yang tersebar di 10 Kabupaten dan Kota di Nusa Tenggara Barat. Sebagai daerah yang memiliki potensi pariwisata yang indah dan melimpah tentunya menjadi daya tarik tersendiri bagi wisatawan untuk berkunjung, sehingga Provinsi Nusa Tenggara Barat menjadi Daerah Tujuan Wisata (DTW) (http://www.disbudpar.ntbprov.go.id/angkakunjungan-wisatawan-ke-ntb/angka-kunjunganwisatawan-tahun-2013-2015/angka kunjungan-wisatawan-2019/angka-kunjungan-wisatawan-triwulan-ii-2019/ diakses tanggal 8 Oktober 2019 pukul 20.00 WITA) 
Menurut Buku Panduan Kelompok Sadar Wisata (Pokdarwis 2012) Daerah Tujuan Wisata (DTW) merupakan kawasan geografis di suatu daerah yang di dalamnya terdapat daya tarik wisata, fasilitas umum, fasilitas pariwisata, aksesibilitas, serta masyarakat yang saling terkait dan melengkapi terwujudnya kepariwisataan. Provinsi Nusa Tenggara Barat sebagai daerah tujuan wisata, Pemerintah Provinsi harus mampu mengelola serta membangun kepariwisataan secara optimal yang meliputi potensi pariwisata, infrastruktur, fasilitas, objek wisata atau wahana rekreasi, dan hal lain yang terkait dengan pariwisata, sehingga dapat meningkatkan kunjungan wisatawan ke suatu daerah termasuk salah satunya Provinsi Nusa Tenggara Barat.

Salah satu desa di Kabupaten Sumbawa yang termasuk desa wisata berdasarkan SK Gubernur NTB tahun 2019 yaitu Desa Marente yang berada pada Kecamatan Alas, Kabupaten Sumbawa. Desa Marente memiliki potensi wisata alam atau ekowisata yang sangat menarik. Desa Marente merupakan desa yang memiliki potensi kekayaan alam yang melimpah karena terdapat hutan yang sangat indah, sangat produktif dan sangat lebat sehingga menjadi sumber air bagi beberapa kecamatan disekitar Kecamatan Alas (https://www.ntbprov.go.id./post/tetapkan-99desapeprov-awali-dengan-25-desa-wisata ). Awal tahun 2014 Desa Marente mulai terkenal dengan wisata air terjun berkat partisipasi komunitas-komunitas pemerhati pariwisata Kabupaten Sumbawa. Selama ini melalui kelompok sadar wisata Desa Marente dengan dukungan dari rekan-rekan komunitas pemerhati pariwisata Sumbawa menginginkan Desa Marente memiliki standar destinasi wisata yangsesuai dengan kondisi Sapta Pesona.Namun, keterbatasan dari segi daya dukung yang memperlambat pengembangan lokasi tersebut karena selama pengelolaan dari awal hanya sebatas kemampuan swadaya masyarakat rekan-rekan (Karang Taruna, Remaja Masjid). Sedangkan pemerintah ataupun swasta belum ada kontribusi dalam hal pendanaan (Sagara, POKDARWIS. 2019)

Berdasarkan hasil observasi awal peneliti, Selain itu dalam pengembangan pariwisata di Desa Marente, ada masyarakat yang menerima dan ada pula masyarakat yang kurang mendukung adanya pengembangan wisata. Hal ini dapat dilihat dari perilaku masyarakat yang ikut berkontribusi dalam pengembangan seperti masyarakat yamg berdagang dan masyarakat yang menjadi tukang parkir di area objek wisata dan 
ada masyarakat yang melakukan hal-hal yang tidak mendukung adanya objek wisata sep erti menebang pohon secara liar disepanjang jalur air terjun dan membuang sampah tidak pada tempatnya. Kurangnya kesadaran dari masyarakat seperti inilah yang menghambat perkembangan pariwisata disuatu daerah.

Saat ini Desa Marente sedang dalam pengembangan objek wisata sehingga dalam pengembangan memerlukan modal sosial dari masyarakat yang berada pada kawasan objek wisata. Modal sosial diperlukan agar masyarakat dapat menghadapi segala permasalahan- permasalahan yang terjadi pada saat pengembangan ekowisata, baik itu permasalahan internal yang ada pada masyarakat dan objek wisata maupun permasalahan eksternal dari wisatawan ataupun pemerintah. Oleh sebab itu modal sosial dari masyarakat perlu dimaksimalkan agar pengembangan dapat berjalan sesuai dengan harapan dan dapat mensejahterakan masyarakatnya. Berdasarkan latar belakang tersebut maka peneliti tertarik untuk melakukan penelitian yang berjudul "Modal Sosial dalam Pengembangan Ekowisata di Desa Marente Kecamatan Alas Kabupaten Sumbawa" dengan beberapa rumusan masalah yaitu bagaimana bentuk modal sosial dalam pengembangan ekowisata di Desa Marente dan bagaimana kendala dan upaya dalam mengatasi persoalan pengembangan ekowisata di Desa Marente. Sehingga tujuan dari penelitian ini yaitu untuk mengetahui bentuk modal sosial serta kendala dan upaya dalam pengembangan ekowisata di Desa Marente.

\section{Metode Penelitian}

Pendekatan penelitian yang digunakan dalam penelitian ini adalah penelitian deskriptif kualitatif. Penelitian deskriptif kualitatif adalah penelitian yang bertujuan memberikan gambaran secara jelas dan sistematis terkait dengan objek yang diteliti dengan memberikan informasi dan data yang valid terkait dengan data dan fenomena yang ada dilapangan. Metode deskriptif adalah metode dalam meneliti suatu kondisi atau peristiwa pada masa sekarang ini yang bertujuan untuk membuat deskriptif atau lukisan secara sistematis, faktual dan aktual mengenai fakta-fakta, nilai-nilai serta hubungan antar fenomena yang diselidiki, (Sugiyono. 2016). Penelitian ini mengambil lokasi di Desa Marente, Kecamatan Alas, Kabupaten Sumbawa. Adapun alasan peneliti mengambil lokasi ini yaitu karena desa ini merupakan salah satu desa di Kabupaten Sumbawa yang memiliki potensi alam yang komplit mulai dari hutan, 
pegunungan, air terjun, perikanan, pertanian bahkan kesenian dan saat ini objek wisata di Desa Marente sedang dalam pengembangan dengan mengangkat konsep ekowisata.. Menurut Arikunto (2010), unit analisis adalah satuan tetentu yang diperhitungkan sebagai subjek penelitian. Maka unit analisis dalam penelitian ini adalah masyarakat yang berada di kawasan objek wisata Desa Marente.

Teknik penentuan informandilakukan dengan menggunakan teknik purposive sampling yaitu penentuan informan dengan melihat atau mempertimbangkan beberapa hal tertentu yang menjadi kriteria dari sasaran informan yang diinginkan. Adapun kriteria-kriteria yang digunakan peneliti dalam purposive sampling yakni masyarakat yang bertempat tinggal dikawasan objek wisata, masyarakat yang berdagang dikawasan objek wisata serta Pihak- pihak terkait atau pendukung dalam pengembangan ekowisata Desa Marente. Teknik pengumpulan data menggunakan wawancara, observasi dan dokumentasi. Pengumpulan data dilakukan dari tanggal 6 Februari sampai 10 Maret 2020. Teknik analisis menggunakan teknik analisis dari Milles dan Hubberman (Sugiyono, 2016) yaitu reduksi data, penyajian data dan penarikan kesimpulan.

\section{Hasil dan Pembahasan}

Berdasarkan wawancara yang telah dilakukan didapatkan hasil mengenai bentuk modal sosial dalam pengembangan ekowisata di Desa Marente dan kendala serta upaya yang dilakukan untuk mengatasi permasalahan pengembangan ekowisata di Desa Marente. Dari hasil penelitian tersebut kemudian dianalisis menggunakan teori modal sosial dari Putnam (Lawang, 2004) dan Woolcock (2001).

Putnam (Lawang, 2004)) memperesentasikan bahwa modal sosial adalah sumber daya individu dan kelompok untuk membentuk sebuah komitmen dalam melakukan kepentingan bersama. Sesuai dengan definisi Putnam (Lawang, 2004) teridentifikasi modal sosial yang ada di Desa Marente, antara lain masyarakat Desa Marente khususnya pengelola ekowisata membentuk aturan-aturan dalam melakukan pengembangan ekowisata yang merupakan suatu komitmen bersama agar pengembangan dapat berjalan sesuai dengan apa yang telah direncanakan. Aturanaturan tersebut berupa larangan kepada masyarakat maupun wisatawan untuk tidak 
membawa dan minum-minuman keras di area objek wisata, larangan kepada wisatawan asing untuk tidak menggunakan pakaian yang terbuka atau tidak sopan di pemukiman warga pada saat berjalan menuju objek wisata, aturan untuk menjaga dan melestarikan lingkungan agar tetap bersih dan asri serta tidak merusak fasilitas objek wisata dengan cara tidak membuang sampah sembarangan dan tidak menebang pohon di area objek wisata. Komitmen yang dibentuk oleh pengelola ekowisata ini merupakan norma sosial agar masyarakat dapat memenuhi kewajibannya dalam mengembangkan ekowisata di Desa Marente sehingga adanya ikatan timbal balik diantara masyarakat dengan objek wisata yang ada, dan objek wisata akan terjaga jika masyarakat memenuhi komitmen yang telah dibentuk.

Norma sosial yang telah dibuat oleh masyarakat Desa Marente merupakan aturan yang tidak tertulis namun tetap dilaksanakan dalam melakukan pengembangan ekowisata. Aturan-aturan tersebut dibuat tidak lepass dari nilai-nilai yang ditanamkan dalam kehidupan masyarakat baik itu untuk kehidupan sehari-sehari maupun untuk pengembangan ekowisata. Nilai-nilai tersebut meliputi sikap kerama-tamahan, nilai kebersamaan, nilai kepedulian terhadap lingkungan baik itu kebersihan lingkungan maupun lingkungan sosial masyarakatnya serta nilai agama. Dasar teori putnam menekankan bahwa kapital sosial sebagai suatu nilai tentang kepercayaan timbal balik (mutual trust) antara anggota masyarakat maupun masyarakat secara keseluruhan terhadap pemimpinnya. Sehingga masyarakat di Desa Marente dalam menjaga komitmen dalam melakukan pengembangan ekowisata telah membangun suatu kepercayaan/trust yang berupa kepercayaan masyarakat dengan pengelola ekowisata. Hal ini terlihat dari eratnya hubungan kekeluargaan dan kekerabatan antara masyarakat dengan pengelola ekowisata sehingga masyarakat yakin bahwa jika mereka bisa bersatu dan saling mempercayai satu sama lain, maka mereka dapat mengembangkan potensi desanya melalui pengembangan ekowisata seperti apabila pengelola ekowisata memerlukan bantuan tenaga ataupun swadaya dari pedagang atau masyarakat untuk memperindah objek wisata maka pedagang atau masyarakat tidak segan untuk memberikannya. 
Selanjutnya kepercayaan pemerintah dan dinas terkait terhadap masyarakat dan pengelola ekowisata (POKDARWIS) Desa Marente. Hal ini terlihat pada satu acara yang digelar oleh pemerintah provinsi di Desa Marente yang melibatkan agen tour and travel se- Indonesia yang merupakan acara sekaligus ajang promosi ekowisata di Desa Marente. Acara tersebut melibatkan masyarakat, perangkat desa, POKDARWIS, perangkat kecamatan serta dinas pariwisata. Masyarakat diberikan kepercayaan untuk menyiapkan dan mengontrol acara tersebut dan buktinya acara tersebut berjalan lancar sesuai dengan apa yang direncanakan. Kepercayaan ini merupakan suatu timbal balik yang dapat menguntungkan semua pihak dalam melakukan pengembangan ekowisata. Selain itu ada kepercayaan diantara masyarakat dengan pengelola wisata serta pihak-pihak yang terkait dalam pengembangan ekowisata muncul karena ikatan kekeluargaan dan kekerabatan diantara mereka. Mereka yakin bahwa jika mereka bisa bersatu dan saling mempercayai satu sama lain, maka mereka dapat mengembangkan potensi desanya melalui pengembangan ekowisata. Kepercayaan yang terjalin dianatara mereka menunjukkan interaksi dalam melakukan pengembangan ekowisata, kepercayaan yang dimiliki oleh pengelola ekowisata terhadap masyarakat mampu untuk melihat seberapa besar kepercayaan dapat mempengaruhi keberlangsungan pengembangan ekowisata.

Kapital sosial ini dilihat sebagai institusi sosial yang melibatkan jaringan (networks), norma-norma (norms) dan kepercayaan sosial (social trust) yang mendorong pada sebuah kolaborasi sosial (koordinasi dan kooperasi) untuk kepentingan bersama. Hal ini juga mengandung pengertian bahwa diperlukan adanya suatu social networks (networks of civic engagement) ikatan/jaringan sosial yang ada dalam masyarakat dan norma yang mendorong produktivitas komunitas. Oleh karena itu dalam pengembangan ekowisata di Desa Marente tidak terlepas dari bantuanbantuan orang luar desa yang memberikan masukan-masukan dan pelatihan agar masyarakat mendapatkan pengetahuan yang lebih maju dalam pengembangan potensi ekowisata di Desa Marente. Sehingga masyarakat Desa Marente melakukan hubungan kerjasama dengan Pemerintah Desa. 
Hubungan kerjasama antara masyarakat dengan pemerintah dalam perencanaan, pelaksanaan, hingga evaluasi dapat terlihat dalam pengembangan ekowisata dilakukan dengan arahan dan persetujuan dari pihak desa karena pihak desa lebih berwenang dalam mengambil keputusan, namun segala ide berasal dari masyarakat dan pengelola wisata. Kemudian hubungan kerja sama masyarakat dengan Pemerintah Kabupaten khususnya Dinas Pemuda Olahraga dan Pariwisata (DISPOPAR) dapat terlihat dari pelatihan-pelatihan pemerhati wisata yang digelar oleh dinas pariwisata Kabupaten Sumbawa untuk masyarakat Desa Marente yang bersedia menjadi pengelola wisata untuk mendapatkan ilmu pengetahuan tentang strategi manajemen pengelolaan wisata. Selanjutnya Pemerintah Provinsi juga terlibat dalam pengembangan ekowisata di Desa Marente. Hal ini terlihat dari hubungan yang terjalin antara Gubernur NTB dengan masyarakat Desa Marente yang sangat erat sehingga Gubernur memberikan informasi dan kepercayaan kepada Desa Marente untuk dijadikan sebagai salah satu desa wisata di NTB. Dengan adanya jaringan sosial ini masyarakat khususnya pengelola ekowisata lebih produktif dan aktif dalam menjalankan tugasnya sebagai pelaku ekowisata.

Menurut Woolcock (2001) dalam Fauziah (2015) Modal sosial dibedakan menjadi tiga tipe yaitu bounding social capital (modal sosial yang mengikat), bridging social capital (modal sosial yang menjembatani) dan linking social capital (modal sosial yang mengaitkan) yang dapat bekerja tergantung dari keadaannya. Tipe modal sosial dapat bekerja dalam kelemahan maupun kelebihan dalam suatu masyarakat, tergantung bagaimana cara individu dan masyarakat memaknainya. Tiga tipe modal sosial memiliki peran dalam proses pengembangan ekowisata yang memiliki kepentingan untuk mengadakan hubungan. Dalam proses pengembangan ekowisata ada nilai dan norma serta kepercayaan terhadap hubungan kerja sama dengan berbagai pihak yang menjadi perekat dan solidaritas masyarakat untuk kelancaran pengembangan ekowisata di Desa Marente.

Tipe modal sosial bounding social capital (modal sosial yang mengikat) yaitu tipe modal sosial yang dalam sistem kemasyarakatannya memiliki ikatan hubungan yang kuat dan saling memiliki rasa solidaritas yang tinggi dengan kelompok lain. Didalam lingkungan masyarakat masih memegang teguh tradisi dan adat istiadat yang berupa nilai atau norma adat, budaya lokal dan kebiasaan sesuai dengan aturan-aturan 
yang ada dalam kehidupan sehari-hari (Woolcock, 2001). Oleh karena itu dalam pengembangan ekowisata di Desa Marente masyarakatnya memegang teguh norma, nilai dan adat istiadat suku Samawa sehingga dalam satu desa memiliki ikatan kekeluargaan yang sangat kuat. Hal tersebut dapat dilihat dalam sikap keramahtamahan masyarakat dalam menjamu wisatawan yang datang berkunjung dan melakukan rutinitas gotong royong oleh masyarakat perangkat desa serta POKDARWIS untuk membersihkan objek wisata setiap minggunya. Selain itu solidaritas sosial dalam pengembangan ekowisata dapat terlihat dari sebuah acara yang digelar di Desa Marente sebagai ajang promosi ekowisata, masyarakat dan stakeholder terkait bekerja sama atau bekerja secara bergotong royong untuk menyukseskan kegiatan tersebut dan solidaritas diantara mereka bisa dibilang cukup kuat. Kemudian masyarakat juga ditanamkan nilai agama seperti berpakaian yang tertutup atau sopan, tidak meminum minuman keras yang memabokkan, saling menghargai atau toleransi, menjaga kebersihan karena kebersihan adalah sebagian dari Iman dan lain sebagainya baik itu dalam kehidupan sehari-hari maupun dalam melakukan pengembangan ekowisata agar masyarakat tidak melakukan hal-hal diluar batas kewajaran.

Tipe modal sosial bridging social capital (modal sosial yang menjembatani) merupakan ikatan sosial yang timbul sebagai reaksi atas berbagai macam karakteristik kelompoknya. Ia bisa muncul karena adanya berbagai macam kelemahan yang ada didalamnya sehingga memutuskan untuk membangun kekuatan dari luar dirinya (Woolcock, 2001). Pengembangan ekowisata di Desa Marente tidak terlepas dari berbagai kendala yang dihadapinya, hal ini merupakan suatu kelemahan yang muncul didalam masyarakat desa sehingga mereka memerlukan bantuan dari pihak luar untuk mengatasi masalah tersebut. Kelemahan tersebut berupa kurangnya SDM yang belum mengetahui tentang manajemen pengelolaan ekowisata. Oleh karena itu masyarakat memerlukan bantuan dari Dinas Pariwisata untuk memberikan pelatihan manajemen pengelolaan pariwsata kepada masyarakat khususnya POKDARWIS Desa Marente. Tidak hanya itu terdapat juga masalah kebersihan yang dimana hal ini merupakan masalah yang penting untuk menunjang pengembangan ekowisata. Sehingga masyarakat harus memiliki kesadaran akan pentingnya kebersihan, oleh karena itu 
masyarakat memerlukan bantuan dari pihak luar seperti Dinas Pariwisata maupun pihak kecamatan untuk memberikan sosialisasi pentingnya kebersihan.

Kelemahan dalam pengembangan ekowisata selanjutnya yaitu masalah dana, yang dimana dana merupakan hal utama yang harus ada didalam pengembangan ekowisata karena dengan adanya dana maka fasilitas dan sarana prasarana objek wisata dapat terpenuhi termasuk sarana teknologi yang dimana pengelola ekowisata memerlukan kamera anti air untuk dokumentasi kegiatan wisata air namun hingga saat ini masih menggunakan handphone dan pelindung anti air. Sehingga masyarakat, pengelola wisata, pemerintah desa dan pemerintah kabupaten telah melakukan berbagai upaya untuk mengatasi kendala yang terjaadi diantaranya yaitu yang dilakukan oleh masyarakat dan pengelola wisata dalam mengatasi masalah yang terjadi yaitu terkait kendala SDM, pengelola melakukan kegiatan yang dimana seluruh masyarakat terlibat didalamnya agar masyarakat memiliki jiwa yang sadar akan pentingnya pariwisata di desa mereka serta ditambah juga dengan mengadakan sosialisasi mengenai pentingnya kebersihan diarea objek wisata agar pengembangan ekowisata tidak terhambat. Sehingga masyarakat serta pengelola wisata bahkan pemerintah desa memiliki kegiatan bersih-bersih objek wisata yang rutin dilakukan seminggu sekali.

Selanjutnya upaya yang dilakukan oleh dinas pariwisata untuk mengatasi masalah kurangnya sumber daya manusia, mereka mengadakan pelatihan-pelatihan kepada masyarakat yang bersedia untuk menjadi pengelola ekowisata di Desa Marente dengan mendatangkan ahli-ahli wisata dari luar daerah agar masyarakatnya mendapatkan ilmu pengetahuan yang lebih tentang manajemen pengelolaan ekowisata untuk menjadikan sumber daya manuasia yang kompeten dalam mengelola objek wisata di Desa Marente. Selanjutnya terkait masalah dana, dari perangkat desa telah mengupayakan untuk melakukan kerja sama dengan pemerintah kabupaten atau anggota dewan agar memberikan bantuan kepada Desa Marente. Kemudian pengelola wisata telah mengajukan proposal anggaran dana kepada pemerintah dan dinas-dinas terkait, namun saat ini belum ada realisasi dana yang diberikan. Sehingga pengelola wisata beserta masyarakat melakukan swadaya dari hasil kegiatan wisata untuk memenuhi kebutuhan ekowisata 
Tipe modal sosial linking social capital (modal sosial yang mengaitkan) yaitu adanya keterkaitan hubungan diantara individu ataupun kelompok dalam suatu masyarakat dengan jaringan ataupun relasi yang diluar lingkungan masyarakat tersebut dan memiliki perbedaan kepentingan antar keduanya. Jaringan yang dibangun oleh masyarakat Desa Marente dengan stakeholder di luar desa memiliki peran menghubungkan masyarakat dengan pemerintah terkait pengembangan ekowisata. Rasa percaya yang diberikan oleh masyarakat Desa Marente terhadap pemerintah merupakan suatu bentuk kerjasama agar masyarakat mendapatkan informasi dan pelatihan-pelatihan untuk mendapatkan sumber daya manusia yang kompeten dalam pengembangan ekowisata di Desa Marente. Walaupun hingga saat ini masyarakat masih menunggu realisasi dana yang dijanjikan pemerintah kepada Desa Marente. Tetapi tingkat kepercayaan masyarakat khususnya pengelola ekowisata terhadap pemerintah masih sama seperti dulu karena bantuan dari pemerintah tidak hanya tentang dana tetapi masih banyak kontribusi pemerintah yang lainnya dalam pengembangan ekowisata. Sebaliknya pemerintah memberikan kepercayaan kepada masyarakat untuk mengembangkan ekowisata di Desa Marente dengan kontribusi pemerintah seperti pelatihan-pelatihan yang di berikan kepada masyarakat, sosialisasi dan lain sebagainya. Hal ini dilakukan agar pariwisata di kabupaten Sumbawa dapat di kenal oleh seluruh masyarakat Indonesia maupun manca negara.

\section{Kesimpulan}

Berdasarkan hasil penelitian dapat ditarik kesimpulan yaitu bentuk modal sosial masyarakat Desa Marente dalam pengembangan ekowisata meliputi (1) nilai dan norma berupa, sikap keramah-tamahan dan nilai kebersamaan yang berasal dari adat istiadat suku Samawa, nilai kepedulian terhadap lingkungan alam maupun lingkungan sosial, nilai agama, larangan kepada masyarakat maupun wisatawan untuk membawa dan meminum minuman keras di area objek wisata, larangan kepada wisatawan asing untuk menggunakan pakaian yang terbuka atau tidak sopan di pemukiman warga pada saat berjalan menuju objek wisata, aturan untuk menjaga dan melestarikan lingkungan agar tetap bersih dan asri serta tidak merusak fasilitas objek wisata. (2) kepercayaan (trust), berupa kepercayaan diantara masyarakat dengan 
pengelola wisata serta pihak-pihak yang terkait dalam pengembangan ekowisata seperti pemerintah desa, kecamatan, kabupaten khususnya Dinas Pariwisata dan pemerintah provinsi muncul karena ikatan kekeluargaan dan kekerabatan diantara mereka, kepercayaan pemerintah atau stakehlder kepada masyarakat. (3) jaringan (network),) berupa hubungan kerja sama masyarakat Desa Marente, POKDARWIS Desa Marente, Pemerintah Desa Pemerintah Kabupaten dan Pemerintah Provinsi dalam melakukan pengembangan ekowisata di Desa Marente. Kendala dan upaya dalam pengembangan ekowisata di Desa Marente meliputi: (1) kendala, berupa dana yang dijanjikan oleh pemerintah belum ada realisasi sehingga sarana dan prasarana serta teknologi belum tercapai untuk menunjang pengembangan ekowisata, kurangnya SDM yang kompeten, masyarakat yang belum sadar akan pentingnya pariwisata, masyarakat yang belum bisa menerima adanya pariwisata, masyarakat yang belum bisa menjaga kebersihan. (2) upaya, berupa pengelola wisata telah mengajukan proposal anggaran dana kepada pemerintah dan dinas-dinas terkait, pemerintah memberikan pelatihan-pelatihan kepada masyarakat khususnya pengelola ekowisata agar menghasilkan SDM yang kompeten dalam melakukan pengembangan ekowisata, memberikan sosialisasi mengenai pentingnya pariwisata dan kebersihan dilingkungan objek wisata Desa Marente yang dilakukan oleh pemerintah desa.

\section{Daftar Pustaka}

Arikunto, S. 2010. Prosedur Penelitian Suatu Pendekatan Praktik. Jakarta: Rineka Cipta. Fauziah, Nurul. 2015. Hubungan Modal Sosial Dengan Kesejahteraan Ekonomi Rumah Tangga Petani. Departemen Sains Komunikasi Dan Pengembangan Masyarakat Fakultas Ekologi Manusia Institut Pertanian Bogor.

Asmin, Fardinal. 2017. EkowisataDan Pembangunan Berkelanjutan: Dimulai dari konsep sederhana. Ebook

http:/www.disbudpar.ntbprov.go.id/angka-kunjungan-wisatawan-ke-ntb/angkakunjungan wisatawan-tahun-2013-2015/angka-kunjungan-wisatawan2019/angka-kunjungan- wisatawan-triwulan-ii-2019/ (diakses tanggal 8 Oktober 2019 pukul 20.00 WITA)

https://www.ntbprov.go.id./post/tetapkan-99-desapeprov-awali-dengan-25-desa-wisata (tanggal 8 Oktober 2019 pukul 20.00 WITA)

Lawang, Robert M.Z. 2004. Kapital Social dalam Perspektif Sosiologi Suatu Pengantar. Depok: FISIP UI Press

Rahim, Firmansyah. 2012. Pedoman Kelompok Sadar Wisata. Jakarta: Direktur Jenderal Pengembangan Destinasi Pariwisata Kementerian Pariwisata dan 
Modal Sosial Dalam Pengembangan Ekowisata

di Desa Marente Kecamatan Alas Kabupaten Sumbawa

Ekonomi Kreatif.

Sagara, POKDARWIS. 2019. Proposal Pengadaan Perengkapan Fisik Wisata dan Penunjang) .

Sugiyono. 2016. Metode Penelitian Pendidikan Pendekatan Kuantitatif, Kualitatif, dan R\&D. Bandung: PT.Alfabeta 